\title{
The global-scale impacts of climate change: the QUEST-GSI project
}

\author{
Nigel W. Arnell ${ }^{1}$
}

Received: 15 December 2015 / Accepted: 5 January 2016 / Published online: 14 January 2016

(C) Springer Science+Business Media Dordrecht 2016

\section{Introduction}

In each successive assessment of the Intergovernmental Panel on Climate Change (IPCC) there has been a substantial increase in the numbers of studies investigating the potential impacts of climate change, in an increasingly diverse number of sectors and places. However, the vast majority of these studies have been undertaken at the local and regional scales, and there remain few assessments of the potential consequences of climate change at the global scale: this was the case even in the IPCC's Fifth Assessment Report (IPCC 2014). Most of the published global-scale assessments concentrate on one sector (Table 1), and different studies have used different scenarios and assumptions. This makes it difficult to compare impacts across places, sectors and scenarios. The few published global multi-sectoral studies use either a single climate model (Hayashi et al. 2010) or a small number of climate models (Piontek et al. 2014).

The QUEST-GSI project ${ }^{1}$ was established to undertake a consistent assessment of the potential range in impacts of climate change across the global domain in several sectors. It uses multiple climate models to characterise plausible climate futures with consistent baseline climate and socio-economic data and consistent assumptions, together with a suite of globalscale sectoral impacts models; one component of the project used catchment-scale hydrological models in a set of catchments around the world with consistent scenarios and assumptions.

The QUEST-GSI project developed from the UK 'Fast Track' assessments, which were initially designed to estimate rapidly the impacts of climate change associated with the latest versions of UK Met Office Hadley Centre climate models. The first phase of the Fast Track

\footnotetext{
${ }^{1}$ QUEST was the UK Natural Environment Research Council (NERC) research programme on Quantifying Uncertainty in the Earth System; GSI is a part of QUEST exploring the Global Scale Impacts of climate change.

This article is part of a Special Issue on "The QUEST-GSI Project" edited by Nigel Arnell.
}

Nigel W. Arnell

n.w.arnell@reading.ac.uk

1 Department of Meteorology, and Walker Institute for Climate System Research, University of Reading, Reading, UK 
used HadCM2 with IS92 emissions scenarios (Parry et al. 1999a; Hulme et al. 1999; Table 1) and some early stabilisation scenarios (Arnell et al. 2002), whilst the second focused on HadCM3 and the SRES emissions and socio-economic scenarios, incorporating in some sectors several other climate models (Parry 2004; Arnell et al. 2004; Table 1). Two key lessons were learnt from the Fast Track assessments. First, the estimated global impacts were strongly dependent on the assumed spatial pattern of change in climate, and use of just a few climate models could give a misleading indication of the potential range of future impacts. Second, it was not possible to seek to construct generalised relationships between amount of forcing and climate impact through meta-analysis of studies using different emissions and socio-economic scenarios because it was impossible to separate out the effects of time on the magnitude of impacts. The QUEST-GSI project addressed these two lessons through the use of multiple climate models, and through its experimental design based on pattern-scaling climate model output.

This Special Issue of Climatic Change includes a series of papers presenting some of the major findings of the QUEST-GSI project. This paper provides an overview of the project and its methodology, describes how the results and approach have been used in subsequent assessments, and identifies some lessons learnt from the project as a whole.

\section{Objectives and project approach}

The project had two overall objectives:

(i) to estimate the impacts of specified emissions pathways on impacts in several sectors across the global domain;

(ii) to develop a capacity to rapidly assess impacts under different emissions pathways or temperature trajectories.

The first objective is relatively traditional, except in its focus on harmonised multi-sectoral impacts. The second addresses the challenge of how to extrapolate from scenario-based assessments to estimate impacts under other scenarios - for example, scenarios representing

Table 1 Global-scale assessments of the impacts of climate change

\begin{tabular}{|c|c|}
\hline $\begin{array}{l}\text { Water resources and river } \\
\text { flooding }\end{array}$ & 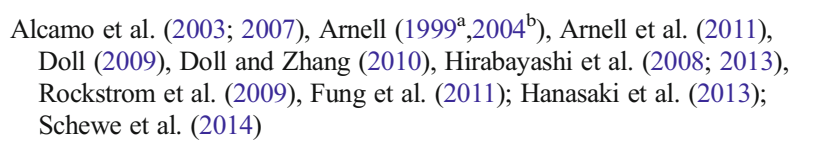 \\
\hline Agriculture and food & $\begin{array}{l}\text { Parry et al. (1999b; 2004 }{ }^{\text {b }} \text {, Fischer et al. (2005; 2007), Tubiello and } \\
\text { Fischer (2007), Tebaldi and Lobell (2008), Hertel et al. (2010), } \\
\text { Deryng et al. (2011); Rosenzweig et al. (2014) }\end{array}$ \\
\hline Terrestrial ecosystems & $\begin{array}{l}\text { White et al. (1999 }) \text {, Cramer et al. (2001), Leemans \& Eickhout (2004); } \\
\text { Levy et al. (2004 }) \text {, Scholze et al. (2006), Schaphoff et al. (2006), } \\
\text { Gonzalez et al. (2010), Heyder et al. (2011); Friend et al. (2014) }\end{array}$ \\
\hline Human health & Martens et al. $\left(1999^{\mathrm{a}}\right)$, van Lieshout et al. $\left(2004^{\mathrm{b}}\right)$ \\
\hline Coastal zones & Nicholls et al. (1999 a ), Nicholls (2004 $\left.{ }^{\mathrm{b}}\right)$, Li et al. (2009); Hinkel et al. (2014) \\
\hline
\end{tabular}

\footnotetext{
${ }^{\text {a }}$ part of the Fast Track first phase

${ }^{\mathrm{b}}$ part of the Fast Track second phase
} 
different potential climate mitigation policies. This second objective was tackled firstly by streamlining the assessment procedure to allow impacts to be estimated rapidly for new emissions scenarios, and secondly by developing force-response functions (similar to Fussel et al. 2003) relating generalised measures of impact to global temperature change.

All the impact models used a consistent set of climate and sea level scenarios, the same baseline climatology (CRU TS3.1: Harris et al. 2013) and the same socio-economic scenarios (from the IMAGE 2.3 characterisations of the four SRES storylines (van Vuuren et al. 2007)) to produce a harmonized global-scale impact assessment.

Climate and sea level rise scenarios were produced by pattern-scaling climate model output, and then rescaling the results to match specified changes in global mean temperature (Osborn et al. 2015). Patterns for change in climate variables and sea level rise were constructed from 21 and 9 CMIP3 climate models (Meehl et al. 2007) respectively, although not all models were used in all impact sectors. A pattern-scaling approach was used rather than simply extracting the appropriate time period from climate model output for two primary reasons. First, it filters out the effect of year-to-year climatic variability and thereby allows clearer comparisons between emissions, models, and years. Second, it allows spatial and seasonal patterns of change in climate and sea level to be estimated for forcings that have not been explicitly simulated by climate models.

Two types of climate scenarios were constructed from the pattern-scaled climate and sea level patterns. The first represents changes under the four SRES (IPCC 2000) emissions pathways, and the second represents changes under prescribed changes in global mean surface temperature. These prescribed change scenarios were used to construct relationships between climate forcing (global mean surface temperature) and impact. The climate scenarios (emissions-based or prescribed) were applied to the CRU TS3.1 1961-1990 baseline climatology (Harris et al. 2013) using the delta method. Patterns of sea level rise were applied to the estimated average 1961-1990 sea level (Brown et al. this issue).

The impact models all operated across the global domain at a spatial resolution of $0.5^{\circ} \times 0.5^{\circ}$ or coastal segment (average length $85 \mathrm{~km}$ ). Table 2 summarises the sectors considered and lists

Table 2 QUEST-GSI global-scale sectors and indicators

\begin{tabular}{ll}
\hline Sector & Description of indicators \\
\hline Water & Change in runoff \\
& Exposure to water resources scarcity \\
Egriculture and food & Exposure to change in river flood risk \\
& Crop productivity \\
Coastal zone & Suitability for crop production \\
Terrestrial ecosystems & Exposure of cropland to drought \\
& Exposure to undernourishment \\
Human health & Exposure to change in coastal flooding \\
& Change in wetland extent \\
Built environment & Soil organic carbon stocks \\
& Ecosystem productivity \\
& Childhood stunting \\
& Storm surge mortality \\
& Residential heating and cooling energy demand
\end{tabular}


some of the indicators of impact. Most of the sectors used established models, but in some cases these were implemented in novel ways (e.g., through use of high-throughput computing: Gosling et al. 2010) or were implemented with new parameterisations (e.g., crop productivity: Osborne et al. 2012). Some new models were developed in the QUEST-GSI project (Lloyd et al. 2011; 2015; Dawson et al. 2014).

Impacts are characterised by different indicator metrics, appropriate to each impact sector, and no attempt is made to aggregate impacts across sectors to produce a single indicator representing the sum or aggregated impact of climate change at a place or in a region. This is because the metrics are expressed in different units, and even if they were made dimensionless (e.g., as quantiles from their distribution across space) any aggregation would involve subjective weighting.

Finally, although most of the analysis was undertaken at the global scale, one part of the project involved the application of a set of catchment-scale hydrological models in different geographic environments, with emissions-based and prescribed climate scenarios from the same seven climate models (Todd et al. 2011). This allowed a comparison of impacts under the same scenarios in the different geographic settings (studies in different catchments have typically used different climate models and approaches to construct scenarios, making comparisons difficult), and also provided an element of 'ground truthing' for the global scale hydrological assessments (Gosling et al. 2011).

\section{Generalisation and development}

The QUEST-GSI project assessed the impacts of climate change across a range of sectors at the global scale for a set of SRES emissions scenarios and prescribed change scenarios (Table 3), and also developed a framework for assessing the implications of different emissions scenarios. One application of this framework has been through the AVOID project ${ }^{2}$ (www.avoid.net), which builds on climate research to understand the causes, effects, and consequences of different climate policies. Within the AVOID project, the QUEST-GSI framework has been used to estimate the impacts (across a subset of sectors) under a series of emissions pathways representing different hypothetical emissions policies with different rates of reduction in emissions, and compared these impacts with those under 'business-as-usual' pathways (Arnell et al. 2013). In this application, climate scenarios were constructed by scaling the CMIP3 climate model patterns to changes in global mean temperature implied by the emissions pathways - an application of the 'streamlined' framework. Another application of the streamlined framework estimated impacts under pathways describing increases in global mean surface temperature which reached 2,3 and $4{ }^{\circ} \mathrm{C}$ above pre-industrial levels by 2100 (Arnell et al. 2015) to provide evidence to support the production of the UK's fifth carbon budget under the 2008 Climate Change Act (Committee on Climate Change 2015). The framework has also been applied in the water sector (Arnell and Lloyd-Hughes 2013) with the new CMIP5 climate models forced by Representative Concentration Pathways (RCPs: Moss et al. 2010; Taylor et al. 2012) and new socio-economic scenarios (O’Neill et al. 2014).

\footnotetext{
$\overline{{ }^{2} \text { Largely funded by the UK Department of Energy and Climate Change (DECC) }}$
} 
Table 3 QUEST-GSI papers

\begin{tabular}{ll}
\hline Sector & Papers \\
\hline Multi-sectoral & Arnell et al. (2013; this issue a, b) \\
Scenarios & Osborn et al. (2015) \\
Water & Arnell et al. (2011), Gosling and Arnell (2011), Gosling et al. (2010); \\
& Haddeland et al. (2011); Arnell and Gosling (2013), Arnell and \\
& Gosling (this issue), Gosling and Arnell (this issue) \\
Catchment-scale & Gosling et al. (2011), Arnell (2011), Hughes et al. (2011), \\
& Kingston and Taylor (2010); Kingston et al. (2011); Nobrega et al. (2011); \\
& Singh et al. (2010); Thorne (2011), Todd et al. (2011), Xu et al. (2011) \\
Agriculture and food & Fraser et al. (2008; 2011; 2013); Osborne et al. (2012); \\
& Simelton et al. (2009; 2012); Dawson et al. (2014) \\
Coastal zone & Nicholls et al. (2011); Brown et al. (this issue) \\
Terrestrial ecosystems & Gottschalk et al. (2012) \\
Human health & Lloyd et al. (2011); Lloyd et al. (2015) \\
\hline
\end{tabular}

\section{Lessons learnt}

An interdisciplinary, multi-sectoral impact assessment using harmonised data and assumptions generates a number of operational challenges. These include the necessity to clarify the details of the experimental design (including such mundane issues as naming conventions) early in the process, the importance of defining transparent priorities for analysis (distinguishing between a 'core set' and an 'extended set', for example), and the need for early consultation on the specific attributes of climate and socio-economic scenarios that are required by different sectors. The QUEST-GSI project also identified two significant technical issues which are more conceptual: how to validate global-scale impacts models, and how to present impacts across sectors and regions in a clear manner, given the uncertainty in the regional pattern of climate change as defined by different climate model scenarios. The validation issue is particularly challenging for the socio-economic impact models because these either estimate exposure to impact rather than actual direct impacts, or estimate actual impacts making generalised assumptions about current and future adaptation measures: the estimated current impacts cannot therefore readily be compared with observations of 'real' impacts (which are in any case often very sparse). Where validation data are not available, global-scale impact models therefore need to be evaluated on the basis of their conceptual underpinnings.

The second conceptual issue - relating to the presentation of results - is more challenging. For a specific sector and in a specific region, it has become common practice in the impacts research community to present the range in, or distribution of, potential impacts across different climate scenarios (for a given level of climate forcing and socio-economic scenario), and often to characterise the overall magnitude of impacts by the ensemble mean or median. However, comparing means (or medians) reduces the variability between regions and sectors, and indeed it is unlikely that any one plausible scenario of regional climate change produces the average change everywhere and for all sectors. Similarly, it is unlikely that the most extreme impacts would occur simultaneously everywhere and in all sectors. One way to resolve this is to construct coherent spatially-variable, multi-sectoral stories from individual climate model scenarios (as in Arnell et al. (this issue a)), but in order to represent uncertainty it is necessary to build many stories. One major lesson learnt in the QUEST-GSI project from 
presentations to different audiences is that different audiences have different requirements so results need to be presented in a wide variety of ways. Some audiences are more concerned with the ranges of potential impacts and are not concerned with whether the extremes can occur at the same time; others are more concerned with synchronous impacts in different places or sectors. Some audiences - typically policy audiences - are keen to see impacts categorised into a small number of classes (for example, low, medium and high), but others typically science audiences - are sceptical of what are seen to be arbitrary class boundaries.

There are, of course, a number of areas where further research is necessary in order to produce more robust assessments of the potential impacts of climate change across sectors, under different plausible climate futures. Three are particularly important. First, in most sectors, the range of potential impacts is large due primarily to uncertainty in the regional distribution of changes in temperature, precipitation, and other relevant dimensions of climate. The more recent CMIP5 generation of climate models does not necessarily reduce the range for a given indicator much (see Arnell and Lloyd-Hughes 2013 and Gosling and Arnell this issue, for examples), so reducing the range in estimates will involve the development of ways of combining climate model output with scientific understanding of potential plausible changes - particularly in atmospheric dynamics (Shepherd 2014). Second, the QUEST-GSI project used one impact model and a small range of impact indicators for each sector. Other models and indicators are available, and incorporating more may allow more robust interpretations of risks. The ISI-MIP project (Warszawski et al. 2014) involves the intercomparison of different impact models, but the effects of using different indicators for a given sector also needs to be evaluated. Third, most of the indicators used in the QUEST-GSI project did not incorporate the effects of adaptation, and the two that did - for coastal and crop productivity impacts - out of necessity made generalised assumptions about how adaptation was implemented and actually worked.

\section{The papers in this issue}

The first paper (Osborn et al. 2015) presents an overview of the pattern-scaling approach used to construct climate scenarios for the QUEST-GSI project, summarising the method and its assumptions. The following papers present impacts in individual sectors, considering in turn water resources (Gosling and Arnell this issue), river flooding (Arnell and Gosling this issue), coastal flooding (Brown et al. this issue) and crop productivity (Rose et al. this issue). They describe the methods used, and present regional and global results. The next two papers focus on two new global-scale impacts models developed in the QUEST-GSI project (simulating malnourishment (Dawson et al. 2014) and coastal flood mortality (Lloyd et al. 2015), and present some initial results. The final two papers are multi-sectoral. The first (Arnell et al. this issue a) summarises the regional and global scale impacts across sectors, synthesising the results presented in the sectoral papers. The second (Arnell et al. this issue b) presents global and regional functions relating impact to change in global mean surface temperature.

Acknowledgments The QUEST-GSI project was funded by the UK Natural Environment Research Council (NERC) under the QUEST programme (grant number NE/E001890/1). The papers in this special issue were all independently peer-reviewed; the papers with Nigel Arnell as an author were edited by Dr. Simon Donner. 


\section{References}

Alcamo J, Doll P, Henrichs T et al (2003) Global estimates of water withdrawals and availability under current and future "business-as-usual" conditions. Hydrol Sci J 48:339-348

Alcamo J, Florke M, Marker M (2007) Future long-term changes in global water resources driven by socioeconomic and climatic changes. Hydrol Sci J 52:247-275

Arnell NW (1999) Climate change and global water resources. Glob Environ Chang 9:S31-S49

Arnell NW (2004) Climate change and global water resources: SRES emissions and socio-economic scenarios. Glob Environ Chang 14:31-52

Arnell NW (2011) Uncertainty in the relationship between climate forcing and hydrological response in UK catchments. Hydrol Earth Syst Sci 15:897-912

Arnell NW, Gosling SN (2013) The impacts of climate change on river flow regimes at the global scale. J Hydrol 486:351-364

Arnell NW, Gosling SN (this issue) The impacts of climate change on river flood risk at the global scale. Clim Chang. doi:10.1007/s10584-014-1084-5.

Arnell NW, Lloyd-Hughes B (2013) The global-scale impacts of climate change on water resources and flooding under new climate and socio-economic scenarios. Clim Chang 122:127-140

Arnell NW, Cannell MGR, Hulme $\mathrm{M}$ et al (2002) The consequences of $\mathrm{CO}_{2}$ stabilisation for the impacts of climate change. Clim Chang 53:413-446

Arnell NW, Livermore MJL, Kovats S et al (2004) Climate and socio-economic scenarios for global-scale climate change impacts assessments: characterising the SRES storylines. Glob Environ Chang 14:3-20

Arnell NW, van Vuuren DP, Isaac M (2011) The implications of climate policy for the impacts of climate change on global water resources. Glob Environ Chang 21:592-603

Arnell NW, Lowe JA, Brown S et al (2013) A global assessment of the effects of climate policy on the impacts of climate change. Nat Clim Chang. doi:10.1038/nclimate1798

Arnell NW, Brown S, Hinkel J et al (2015) The global impacts of climate change under pathways that reach 2, 3 and $4{ }^{\circ} \mathrm{C}$ above pre-industrial levels. Report from the AVOID2 project to the Committee on Climate Change. Available at https://www.theccc.org.uk/publication/

Arnell NW, Brown S, Gosling SN et al (this issue a) A global-scale, multi-sectoral regional climate change risk assessment. Clim Chang. doi 10.1007/s10584-014-1281-2.

Arnell NW, Brown S, Gosling SN, et al. (this issue b) Global-scale climate impact functions: the relationship between climate forcing and impact. Clim Chang. doi 10.1007/s10584-013-1034-7

Brown S, Nicholls RJ, Lowe JA, Hinkel J. (this issue) Spatial variations of sea-level rise and impacts: an application of DIVA. Clim Chang. doi: 10.1007/s10584-013-0925-y

Committee on Climate Change (2015) The fifth carbon budget. The next step towards a low-carbon economy. Committee on Climate Change, London

Cramer W, Bondeau A, Woodward FI et al (2001) Global response of terrestrial ecosystem structure and function to $\mathrm{CO}_{2}$ and climate change: results from six dynamic global vegetation models. Glob Chang Biol 7:357-373

Dawson TP, Perryman AH, Osborne TM (2014) Modelling impacts of climate change on global food security. Clim Chang. doi:10.1007/s10584-014-1277-y

Deryng D, Sacks WJ, Barford CC, Ramankutty N (2011) Simulating the effects of climate and agricultural management practices on global crop yield. Glob Biogeochem Cycles 25. doi: 10.1029/2009gb003765

Doll P (2009) Vulnerability to the impact of climate change on renewable groundwater resources: a global-scale assessment. Environ Res Lett 4, 035006. doi:10.1088/1748-9326/4/3/035006

Doll P, Zhang J (2010) Impact of climate change on freshwater ecosystems: a global-scale analysis of ecologically relevant river flow alterations. Hydrol Earth Syst Sci 14:783-799

Fischer G, Shah M, Tubiello FN, van Velhuizen H (2005) Socio-economic and climate change impacts on agriculture: an integrated assessment, 1990-2080. Philos Trans R Soc B-Biol Sci 360:2067-2083

Fischer G, Tubiello FN, Van Velthuizen H, Wiberg DA (2007) Climate change impacts on irrigation water requirements: effects of mitigation, 1990-2080. Technol Forecast Soc Chang 74:1083-1107

Fraser EDG, Termansen M, Sun N et al (2008) Quantifying socioeconomic characteristics of drought-sensitive regions: evidence from Chinese provincial agricultural data. Compt Rendus Geosci 340:679-688

Fraser EDG, Dougill AJ, Hubacek K et al (2011) Assessing vulnerability to climate change in dryland livelihood systems: conceptual challenges and interdisciplinary solutions. Ecol Soc 16:3. doi:10. 5751/es-03402-160303

Fraser EDG, Simelton E, Termansen M et al (2013) "Vulnerability hotspots": integrating socio-economic and hydrological models to identify where cereal production may decline in the future due to climate change induced drought. Agric For Meteorol 170:195-205

Friend AD, Lucht W, Rademacher TT et al (2014) Carbon residence time dominates uncertainty in terrestrial vegetation responses to future climate and atmospheric $\mathrm{CO}_{2}$. Proc Natl Acad Sci U S A 111:3280-3285 
Fung F, Lopez A, New M (2011) Water availability in +2 degrees C and +4 degrees C worlds. Philos Trans R Soc A-Math Phys Eng Sci 369:99-116

Fussel HM, Toth FL, Van Minnen JG, Kaspar F (2003) Climate impact response functions as impact tools in the tolerable windows approach. Clim Chang 56:91-117

Gonzalez P, Neilson RP, Lenihan JM, Drapek RJ (2010) Global patterns in the vulnerability of ecosystems to vegetation shifts due to climate change. Glob Ecol Biogeogr 19:755-768

Gosling SN, Arnell NW (2011) Simulating current global river runoff with a global hydrological model: model revisions, validation, and sensitivity analysis. Hydrol Process 25:1129-1145

Gosling SN, Arnell NW (this issue) A global assessment of the impact of climate change on water resources. Clim Chang. doi:10.1007/s10584-013-0853-x

Gosling SN, Bretherton D, Haines K, Arnell NW (2010) Global hydrology modelling and uncertainty: running multiple ensembles with a campus grid. Philos Trans R Soc A-Math Phys Eng Sci 368:4005-4021

Gosling SN, Taylor RG, Arnell NW, Todd MC (2011) A comparative analysis of projected impacts of climate change on river runoff from global and catchment-scale hydrological models. Hydrol Earth Syst Sci 15:279294

Gottschalk P, Smith JU, Wattenbach M et al (2012) How will organic carbon stocks in mineral soils evolve under future climate? Global projections using RothC for a range of climate change scenarios. Biogeosciences 9: 3151-3171

Haddeland I, Clark DB, Franssen W et al (2011) Multimodel estimate of the global terrestrial water balance: setup and first results. J Hydrometeorol 12:869-884

Hanasaki N, Fujimori S, Yamamoto T et al (2013) A global water scarcity assessment under Shared Socioeconomic Pathways - Part 2: water availability and scarcity. Hydrol Earth Syst Sci 17:2393-2413

Harris I, Jones PD, Osborn TJ, Lister DH (2013) Updated high-resolution grids of monthly climatic observations - the CRU TS3.10 data set. Int J Climatol 34:623-642

Hayashi A, Akimoto K, Sano F et al (2010) Evaluation of global warming impacts for different levels of stabilization as a step toward determination of the long-term stabilization target. Clim Chang 98:87-112

Hertel TW, Burke MB, Lobell DB (2010) The poverty implications of climate-induced crop yield changes by 2030. Glob Environ Chang 20:577-585

Heyder U, Schaphoff S, Gerten D, Lucht W (2011) Risk of severe climate change impact on the terrestrial biosphere. Environ Res Lett 6. doi: 10.1088/1748-9326/6/3/034036

Hinkel J, Lincke D, Vafeidis AT et al. (2014) Coastal flood damage and adaptation costs under 21st century sealevel rise. Proc Natl Acad Sci 111 (9), doi:101073/pnas1222469111

Hirabayashi Y, Kanae S, Emori S, Oki T, Kimoto M (2008) Global projections of changing risks of floods and droughts in a changing climate. Hydrol Sci J 53:754-772

Hirabayashi Y et al (2013) Global flood risk under climate change. Nat Clim Chang 3:816-821. doi:10.1038/ nclimate 1911

Hughes DA, Kingston DG, Todd MC (2011) Uncertainty in water resources availability in the Okavango River basin as a result of climate change. Hydrol Earth Syst Sci 15:931-941

Hulme M, Mitchell JFB, Ingram M et al (1999) Climate change scenarios for global impacts studies. Glob Environ Chang 9:S3-S19

IPCC (2000) Special report on emissions scenarios. Cambridge University Press, Cambridge

IPCC (2014) Climate change 2014: impacts, adaptation and vulnerability. Contribution of Working Group II to the Fifth Assessment Report of the Intergovernmental Panel on Climate Change. In: Field CB, Barros VR, Dokken DJ et al (eds). Cambridge University Press, Cambridge. 2 vols.

Kingston DG, Taylor RG (2010) Sources of uncertainty in climate change impacts on river discharge and groundwater in a headwater catchment of the Upper Nile Basin, Uganda. Hydrol Earth Syst Sci 14:12971308

Kingston DG, Thompson JR, Kite GW (2011) Uncertainty in climate change projections of discharge for the Mekong River Basin. Hydrol Earth Syst Sci 15:1459-1471

Leemans R, Eickhout B (2004) Another reason for concern: regional and global impacts on ecosystems for different levels of climate change. Glob Environ Chang 14:219-228

Levy PE, Cannell MGR, Friend AD (2004) Modelling the impact of future changes in climate, $\mathrm{CO}_{2}$ concentration and land use on natural ecosystems and the terrestrial carbon sink. Glob Environ Chang 14:21-30

Li XG, Rowley RJ, Kostelnick JC et al (2009) GIS analysis of global impacts from sea level rise. Photogramm Eng Remote Sens 75:807-818

Lloyd SJ, Kovats RS, Chalabi Z (2011) Climate change, crop yields, and undernutrition: development of a model to quantify the impact of climate scenarios on child undernutrition. Environ Health Perspect 119:1817-1823

Lloyd SJ, Kovats RS, Chalabi Z, Brown S, Nicholls RJ (2015) Modelling the influences of climate changeassociated sea-level rise and socio-economic development on future storm surge mortality. Clim Chang. doi: 10.1007/s10584-015-1376-4 
Martens P, Kovats S, Nijhof S et al (1999) Climate change and future populations at risk of malaria. Glob Environ Chang 9:S89-S107

Meehl GA, Covey C, Delworth T et al (2007) The WCRP CMIP3 multimodel dataset - A new era in climate change research. Bull Am Meteorol Soc 88:1383

Moss RH, Edmonds JA, Hibbard KA et al (2010) The next generation of scenarios for climate change research and assessment. Nature 463:747-756

Nicholls RJ (2004) Coastal flooding and wetland loss in the 21st century: changes under the SRES climate and socio-economic scenarios. Glob Environ Chang 14:69-86

Nicholls RJ, Hoozemans FMJ, Marchand M (1999) Increasing flood risk and wetland losses due to global sea level rise: regional and global analyses. Glob Environ Chang 9:S69-S87

Nicholls RJ, Marinova N, Lowe JA et al (2011) Sea-level rise and its possible impacts given a 'beyond 4 degrees C world' in the twenty-first century. Philos Trans R Soc A-Math Phys Eng Sci 369:161-181

Nobrega MT, Collischonn W, Tucci CEM, Paz AR (2011) Uncertainty in climate change impacts on water resources in the Rio Grande Basin, Brazil. Hydrol Earth Syst Sci 15:585-595

O’Neill BC, Kriegler E, Riahi K et al (2014) A new scenario framework for climate change research: the concept of shared socioeconomic pathways. Clim Chang 122(3):387-400

Osborn TJ, Wallace CJ, Harris IC, Melvin TM (2015) Pattern-scaling using ClimGen: monthly-resolution future climate scenarios including changes in the variability of precipitation. Clim Chang. doi:10.1007/s10584015-1509-9

Osborne TM, Rose GA, Wheeler TR (2012) Variation in the global-scale impacts of climate change on crop productivity due to climate model uncertainty and adaptation. Agric For Meteorol 170:183-194

Parry ML (2004) Global impacts of climate change under the SRES scenarios. Glob Environ Chang 14:1

Parry ML, Arnell NW, Hulme M et al (1999a) The global impact of climate change: a new assessment. Glob Environ Chang 9:S1-S2

Parry ML, Rosenzweig C, Iglesias A, Fischer G, Livermore MTJ (1999b) Climate change and world food security: a new assessment. Glob Environ Chang 9:S51-S67

Parry ML, Rosenzweig C, Iglesias A et al (2004) Effects of climate change on global food production under SRES emissions and socio-economic scenarios. Glob Environ Chang 14:53-67

Piontek F, Muller C, Pugh TAM et al (2014) Multisectoral climate impact hotspots in a warming world. Proc Natl Acad Sci U S A 111:3233-3238

Rockstrom J, Falkenmark M, Karlberg L, et al (2009) Future water availability for global food production: The potential of green water for increasing resilience to global change. Water Resour Res 45. doi: 10.1029/ 2007WR006767

Rose GA, Osborne T, Greatrex H, Wheeler TR (this issue) Impact of progressive global warming on the globalscale yield of maize and soybean. Clim Chang. doi:10.1007/s10584-016-1601-9

Rosenzweig C, Elliot J, Deryng D (2014) Assessing agricultural risks of climate change in the $21^{\text {st }}$ century in a global gridded crop model intercomparison. Proc Natl Acad Sci U S A 111:3268-3273

Schaphoff S, Lucht W, Gerten D et al (2006) Terrestrial biosphere carbon storage under alternative climate projections. Clim Chang 74:97-122

Schewe J, Heinke J, Gerten D et al (2014) Multi-model assessment of water scarcity under climate change. Proc Natl Acad Sci 111:3245-3250

Scholze M, Knorr W, Arnell NW, Prentice IC (2006) A climate-change risk analysis for world ecosystems. Proc Natl Acad Sci U S A 103:13116-13120

Shepherd TG (2014) Atmospheric circulation as a source of uncertainty in climate change projections. Nat Geosci 7:703-708

Simelton E, Fraser EDG, Termansen M et al (2009) Typologies of crop-drought vulnerability: an empirical analysis of the socio-economic factors that influence the sensitivity and resilience to drought of three major food crops in China (1961-2001). Environ Sci Pol 12:438-452

Simelton E, Fraser EDG, Termansen M et al (2012) The socioeconomics of food crop production and climate change vulnerability: a global scale quantitative analysis of how grain crops are sensitive to drought. Food Secur 4:163-179

Singh CR, Thompson JR, French JR et al (2010) Modelling the impact of prescribed global warming on runoff from headwater catchments of the Irrawaddy River and their implications for the water level regime of Loktak Lake, northeast India. Hydrol Earth Syst Sci 14:1745-1765

Taylor KE, Stouffer RJ, Meehl GA (2012) An overview of CMIP5 and the experimental design. Bull Am Meteorol Soc 93:485-498

Tebaldi C, Lobell DB (2008) Towards probabilistic projections of climate change impacts on global crop yields. Geophys Res Lett 35. doi: 10.1029/2008g1033423

Thorne R (2011) Uncertainty in the impacts of projected climate change on the hydrology of a subarctic environment: Liard River Basin. Hydrol Earth Syst Sci 15:1483-1492 
Todd MC, Taylor RG, Osborn TJ et al (2011) Uncertainty in climate change impacts on basin-scale freshwater resources - preface to the special issue: the QUEST-GSI methodology and synthesis of results. Hydrol Earth Syst Sci 15:1035-1046

Tubiello FN, Fischer GI (2007) Reducing climate change impacts on agriculture: global and regional effects of mitigation, 2000-2080. Technol Forecast Soc Chang 74:1030-1056

Van Lieshout M, Kovats RS, Livermore MTJ, Martens P (2004) Climate change and malaria: analysis of the SRES climate and socio-economic scenarios. Glob Environ Chang 14:87-99

van Vuuren DP, Den Elzen MGJ, Lucas PL et al (2007) Stabilizing greenhouse gas concentrations at low levels: an assessment of reduction strategies and costs. Clim Chang 81:119-159

Warszawski L, Frieler K, Huber V et al (2014) The Inter-Sectoral Impact Model Intercomparison Project (ISIMIP): project framework. Proc Natl Acad Sci U S A 111(9):3228-3232

White A, Cannell MGR, Friend AD (1999) Climate change impacts on ecosystems and the terrestrial carbon sink: a new assessment. Glob Environ Chang 9:S21-S30

$\mathrm{Xu} \mathrm{H}$, Taylor RG, Xu Y (2011) Quantifying uncertainty in the impacts of climate change on river discharge in sub-catchments of the Yangtze and Yellow River Basins, China. Hydrol Earth Syst Sci 15:333-344 